\title{
Dosage of Lipid Emulsions as an Antidote to Lipid-Soluble Substances
}

\author{
Gabriela Kehayova, Snezha Zlateva, Petko Marinov \\ Department of Pharmacology, Toxicology and Pharmacotherapy, Faculty of Pharmacy, Medical University of Varna, Varna, Bulgaria
}

Corresponding author: Gabriela Kehayova, Department of Pharmacology, Toxicology and Pharmacotherapy, Faculty of Pharmacy, Medical University of Varna, Varna, Bulgaria; E-mail: gabi_stier@yahoo.com; Tel.: +359 883519926

Received: 1 Oct 2020 Accepted: 4 Nov 2020 Published: 31 Dec 2021

Citation: Kehayova G, Zlateva S, Marinov P. Dosage of lipid emulsions as an antidote to lipid-soluble substances. Folia Med (Plovdiv) 2021;63(6):913-8. doi: 10.3897/folmed.63.e59216.

\begin{abstract}
Introduction: Lipid emulsions are increasingly used as an antidote to lipophilic drug intoxications. The dose recommended by the American Society of Regional Anesthesia is used primarily for the treatment of local anesthetic systemic toxicity. There is insufficient information about what the dose of lipid emulsions (LE) should be in other intoxications depending on their severity.
\end{abstract}

Aim: To determine the LE dose in a shock or haemodynamic instability in patients with acute exogenous intoxications treated with LE.

Materials and methods: Forty-nine patients with acute lipophilic drug intoxications were treated with LE in the Clinic of Toxicology at the Naval Hospital in Varna.

Statistical analysis was performed using the statistical functions of Excel 2016 and the Statistica 7.0 software package.

Results: The percentage of patients receiving a low dose of LE of $0.3 \mathrm{ml} / \mathrm{kg}(93.87 \%)$ was significantly higher than the percentage of patients treated with a medium (2.04\%) and a high dose (4.08\%) of LF. The high dose of LE of $1.5 \mathrm{ml} / \mathrm{kg}$ recommended by the American Society of Regional Anesthesia was administered to two patients (4.08\%). In severe intoxications with exotoxic shock, the rate of LE administration varies from $20 \mathrm{ml} / \mathrm{h}$ to $40 \mathrm{ml} / \mathrm{h}$.

Conclusions: In severe intoxications with cardiotoxic syndrome and haemodynamic instability, LE should be used in the dose as suggested by the American Society of Regional Anesthesia. It is possible to use lower doses of LE in the range of $0.3-0.6 \mathrm{ml} / \mathrm{kg}$ in all moderate poisonings administered by continuous intravenous infusion for 12-24-48 hours. No side effects were observed at these doses.

\section{Keywords}

acute drug intoxication, dosage of lipid emulsion, lipid emulsion

\section{INTRODUCTION}

The incidence of acute drug intoxications is constantly increasing worldwide. The most common cause of overdose is a suicide attempt. The etiological distribution of acute drug intoxications includes mainly antidepressants, neuroleptics, and cardiovascular drugs.

Overdosing of these drugs can often cause fatal complications despite the timely administered therapy, which makes it necessary that more effective treatments such as the intravenous lipid emulsion (LE) therapy should be introduced into routine practice.

The affinity of some drugs to lipids has led to the use of LE as an antidote in the treatment of any lipophilic drug overdose. ${ }^{1}$ Originally designed to provide essential fatty acids for patients who are unable to eat per os, LE has been used in recent years as an antidote in cases of overdosing with local anesthetics and other lipophilic drugs.

The main groups of drugs for which the use of LE has been shown to have a good effect are as follows: 
1. Local anesthetics: bupivacaine, lidocaine, cocaine, ropivacaine;

2. Antidepressants: amitriptyline, citalopram, bupropion, doxepin, imipramine;

3. Antipsychotics: acepromazine, olanzapine, trazodone, quetiapine;

4. Cardiovascular drugs: verapamil, diltiazem, propranolol, amlodipine, carvediol;

5. Others: diphenhydramine, zolpidem, phenytoin, meperidine, carbamazepine, pentobarbital, methamphetamine, zopiclone, glyphosate and some other drugs.

The idea that intravenous LE can be used to influence the pharmacokinetics of a drug that is already in the bloodstream was first introduced more than fifty years ago. ${ }^{2}$ For the first time in 2008, LE was administered as a last attempt to resuscitate a 17-year-old girl after taking an overdose of bupropion and lamotrigine and subsequent total cardiovascular collapse. After seventy minutes of unsuccessful resuscitation, 20\% LE was administered. Within one minute of the application of LE, vital signs were restored. ${ }^{3}$

In recent years, studies have focused on the effects of LE on poisoning with lipophilic drugs such as calcium channel blockers, beta-blockers, antidepressants and other similar drugs. As suicide attempts with these drugs are constantly on the rise worldwide and treatment often proves ineffective, alternative and more successful treatments, such as LE therapy, are being sought.

Due to the ever-increasing number of reports of successful resuscitation, LEs are already present in recent guidelines as a mandatory component in the treatment of verapamil toxicity. ${ }^{4}$

Unlike in many other countries, LEs in Bulgaria have not yet been recognized as a first line treatment in cases of lipophilic drug intoxications. For the first time, LEs were successfully used in Bulgaria in 2012 at the Clinic of Toxicology in Pleven in a case of quetiapine intoxication. In the Clinic of Toxicology at the Naval Hospital, Varna, LEs have been used for the treatment of various drug poisonings and organophosphorus compounds since 2014.

\section{Dosage of lipid emulsions and method of administration as an antidote to fat-sol- uble substances}

In 2010, the American Society of Regional Anesthesia (ASRA) published practical advice for dealing with local anesthetic toxicity, emphasizing the role of LE in the treatment of local anesthetic systemic toxicity (LAST). ${ }^{5}$

These treatment guidelines include the use of LE as an adjunct to cardiopulmonary resuscitation, stating that lipid emulsion therapy can be a tool to facilitate resuscitation through its "lipid sink" effects, which reduces the lipid-soluble local anesthetics content of cardiac tissue, thus improving cardiac conduction, contractility, and coronary perfusion. Also, good pulmonary ventilation should be provided to prevent hypoxia and respiratory acidosis which may potentiate LAST. ${ }^{6}$ As a first choice, LEs are recommended for cardiopulmonary resuscitation in cases of LAST at the initial manifestation of cardiovascular and neurological symptoms.

The practical application of LE in LAST is specified in the guidelines of the Association of Anesthesiologists of Great Britain and Ireland (AAGBI), the American College of Medical Toxicology (ACMT) and ASRA and includes: Lipid emulsion bolus in a dose of $1.5 \mathrm{ml} / \mathrm{kg}$ intravenously for one minute. Recurrence is possible with persistent cardiovascular collapse every 5 minutes.

Continuous intravenous infusion of $0.25 \mathrm{ml} / \mathrm{kg} / \mathrm{min}$ continuing for $20-60 \mathrm{~min}$ ( $15 \mathrm{ml} / \mathrm{kg}$ for $60 \mathrm{~min}$ ) until circulation is restored. The bolus dose may be doubled or the rate of continuous infusion may be doubled in haemodynamic instability. The infusion is continued for at least 10 minutes after recovery of haemodynamics. The upper limit for the total amount of infused solution is $10 \mathrm{ml} / \mathrm{kg}$ for 30 minutes. Despite these recommendations, the amounts of solution administered vary widely in the clinical cases described in the literature. A case of a child receiving $46 \mathrm{ml} / \mathrm{kg} / \mathrm{i} . \mathrm{v}$ for 12 hours in bupropion, hydroxyzine, and citalopram poisoning with mild side effects and successful response to severe hypotension and seizures has been reported. Some authors report effective administration of lower than recommended doses by infusion of $10 \%$ lipid solution or short-term infusion of $200 \mathrm{ml}$ of $20 \%$ lipid solution administered after the initial regular bolus dose. ${ }^{7}$

ASRA does not specify an exact dose for pediatric patients. The recommendations follow the same dosing regimen as in adults: direct intravenous lipid emulsion at a concentration of $1.5 \mathrm{ml} / \mathrm{kg}$ (300 $\mathrm{mg} / \mathrm{kg} / \mathrm{min}) 20 \%$ for at least $1 \mathrm{~min}$. Continue infusion at $0.25 \mathrm{ml} / \mathrm{kg} / \mathrm{min}(50 \mathrm{mg} /$ $\mathrm{kg} / \mathrm{min}$ ) for $30-60$ minutes. If there is no improvement in haemodynamics or if symptoms recur after an initial response: $1.5 \mathrm{ml} / \mathrm{kg}$ intravenous direct dose may be repeated up to 2 times at 5 -min intervals. The infusion can be increased to $0.5 \mathrm{ml} / \mathrm{kg} / \mathrm{min}(100 \mathrm{mg} / \mathrm{kg} / \mathrm{min})$ and can be performed through a peripheral venous route. ${ }^{8}$

In all other acute poisonings with lipophilic toxic agents such as beta-blockers, calcium channel blockers, antidepressants, pesticides, etc., LE is mentioned as a treatment in severe cases refractory to standard therapy with severe cardiovascular insufficiency (shock, arterial hypotension, cardiac arrest). Ten percent and $20 \%$ LE based on various vegetable oils and fish oil is used.

Despite the ever-increasing number of reports from patients and animal experiments for the successful administration of LE, there is a lack of sufficient information on the ways of dosing LE depending on the severity of acute exogenous intoxications. The dose recommended by ASRA applies only to cases of overdose with local anesthetics and is absent in other intoxications other than local anesthesia.

\section{AIM}

The aim of the study was to determine the dosing methods of LE depending on the severity of intoxications (mild, 
moderate, and severe) and monitoring of adverse effects at different dose regimens in patients with acute exogenous intoxications treated with LE as part of a standard therapy in the Clinic of Toxicology at the Naval Hospital, Varna.

\section{MATERIALS AND METHODS}

\section{Materials}

The study included 49 patients with acute drug intoxications other than overdose with local anaesthetics who were admitted to the Clinic of Toxicology at the Naval Hospital, Varna and treated with LE as part of the standard resuscitation and detoxification depuration therapy.

The study is retrospective and covers an 8-year period from 2010 to 2018 . The access to the medical documentation was provided with the permission of the Ethics Commission at the Naval Hospital, Varna.

\section{Methods}

The history of the disease, the conducted treatment, including LE, the performed laboratory and instrumental examinations, and the outcome of the therapy in the Clinic of Toxicology at the Naval Hospital in Varna were studied.

\section{Statistical analysis}

Statistical analysis was performed using the statistical functions of Excel 2016 and Statistica 7.0 software packages. In all performed statistical analyses, an acceptable level of confidence probability $p<0.05$ was assumed, divided into three ascending classes: $p<0.05, p<0.01$ (high significance), and $p<0.001$ (very high significance).

\section{RESULTS AND DISCUSSION}

The most commonly overdosed drugs are benzodiazepines, neuroleptics and SSRI antidepressants, calcium channel blockers, beta blockers, and cardiac glycosides.

Analysis of the medical documentation shows that LEs were applied for the first time in the Clinic of Toxicology at the Naval Hospital, Varna in 2014. In 2018, the highest frequency of application of LE was observed (21.5\%) as an antidote in the overall detoxification-depuration treatment doctrine, adopted and approved by the Bulgarian Society of Clinical Toxicology.

According to the data by the Bulgarian Drug Agency at the Ministry of Health of the Republic of Bulgaria, among the intravenous emulsions available on the Bulgarian market are Intralipid 20\% (Fresenius Kabi AB), lipofundin MCT/LCT 10\% and 20\% (B. Braun Melsungen AG), kabiven (Fresenius Kabi AG), oliclinomel (Baxter S.A.), periolimel (Baxter S.A), omegaven (Fresenius Kabi Austria $\mathrm{GmbH}$ ), nutriflex (B. Braun Melsungen AG), structolipid
(Fresenius Kabi AG), and smofkabiven (Fresenius Kabi AG) (Register, 2019). ${ }^{9}$

For technical reasons, different LE were administered during the study period: Intralipid $20 \%$ was administered to 30 patients $(61.22 \%)$, lipovenous $10 \%$ to 9 (18.36\%), kabiven to 7 patients $(14.28 \%)$, and periolimel to 3 patients $(6.12 \%)$.

The analysis showed that the number of patients with Intralipid $20 \%$ was significantly higher than the number of patients with other types of emulsion $(p<0.001)$.

The dosage of LE as an antidote in the Clinic of Toxicology at the Naval Hospital-Varna varies depending on the severity of the intoxication.

Acute exogenous intoxications are divided into mild, moderate, and severe. The severity is determined by the number of medications taken and the clinical symptoms.

Mild acute exogenous intoxications are characterized by stable hemodynamics, consciousness is preserved and there are no pulmonary complications. Such intoxication was observed in $93.87 \%$ of the patients.

In moderate acute exogenous intoxications, there is a slight instability in hemodynamics, changes in consciousness to somnolence, but without pulmonary complications. These are observed in $2.04 \%$ of patients.

Severe acute exogenous intoxications are those with hypotension or exotoxic shock, changes in consciousness to sopor and coma, and pulmonary complications such as pulmonary congestion and aspiration pneumonia. These are observed in $4.08 \%$ of patients.

Fig. 1 shows the number and percentage of patients treated with low, medium, and high doses of LE.

Different groups of patients were treated with different dosage regimens. In severe intoxications with cardiotoxic syndrome and haemodynamic instability, the dose of LE is that determined by ASRA, namely a bolus of $1.5 \mathrm{ml} / \mathrm{kg}$ for 5 minutes, followed by a continuous infusion at a dose of $6 \mathrm{ml} / \mathrm{kg}$. In all mild poisonings it is possible to administer lower doses of LE $0.3-0.6 \mathrm{ml} / \mathrm{kg}$ as a continuous intravenous infusion for 12-24-48 hours.

The percentage of patients with low dose of LE of 0.3 $\mathrm{ml} / \mathrm{kg}(93.87 \%)$ was significantly higher than the percentage of patients with a medium $(2.04 \%)$ and a high dose $(4.08 \%)(p<0.001)$. In most of the described clinical cases in the available literature, LE has been administered according to the ASRA regimen. ${ }^{10-19}$

In the present study, the increased use of low-dose LE was explained by the careful approach to the new drug and possible side effects of LE, as well as by the fact that most patients with acute intoxication treated with low dose of LE were hemodynamically stable.

The high dose of LE of $1.5 \mathrm{ml} / \mathrm{kg}$ recommended by ASRA was administered to two patients (4.08\%). In severe intoxications with exotoxic shock, the rate of administration varies from $20 \mathrm{ml} / \mathrm{h}$ to $40 \mathrm{ml} / \mathrm{h}$.

All patients who received LE were monitored clinically and by lab tests for adverse reactions. The results showed that no matter what the dose regimen was, no side effects such as pulmonary edema, thrombocytopenia, embolism, 


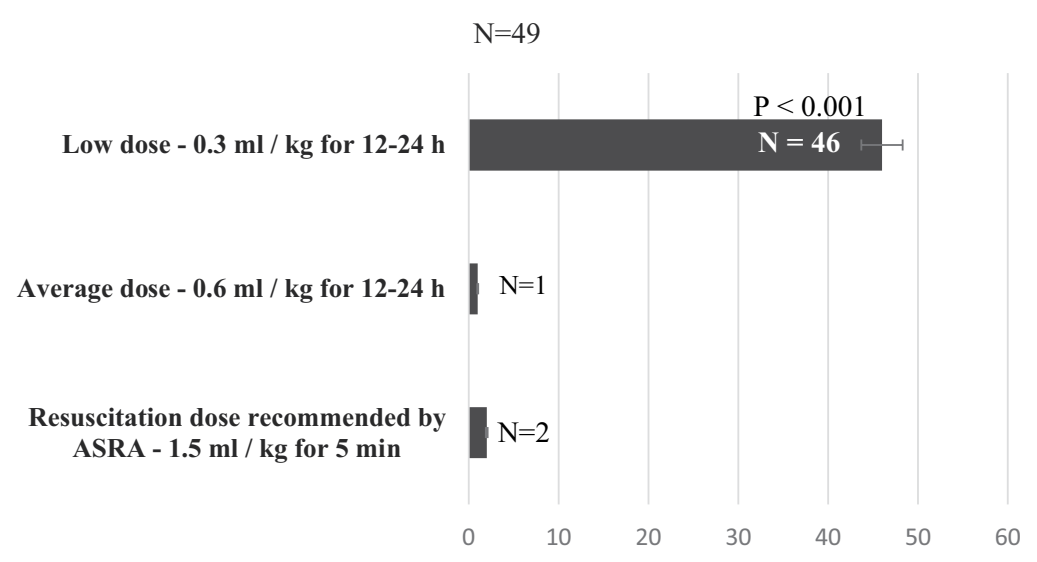

Figure 1. Dosage of LE at the Clinic of Toxicology at the Naval Hospital, Varna.

shock, and elevated transaminases were observed.

Based on the obtained results, a Table 1 has been developed, reflecting the ways of dosing LE depending on the severity of the intoxication, which should be at hand for clinicians for reference and clinical application:

The proposed treatment regimen contributes to improving the quality of treatment of patients with acute lipophilic drug intoxications, with high degree of certainty for absence of side effects, reducing the duration of hospital stay, the cost of treatment, and the risk of fatal outcome.

\section{CONCLUSIONS}

The number of acute drug intoxications with lipophilic drugs is constantly increasing, and due to severe cerebroand cardiotoxicity, mortality remains high worldwide. As an antidote, LE has not yet entered routine medical practice. Therefore, the results of the study confirm the safety and the possibility of LE to be used effectively in different dosage regimens, according to the severity of the clinical picture. Researchers suggest that in all acute intoxications with lipophilic drugs, regardless of their severity, parenteral lipid infusion should be included in the complex treatment as early as possible.

\section{Acknowledgements}

The author Gabriela Kehayova would like to thank her supervisors Prof. Snezha Zlateva and Prof. Petko Marinov for their support and valuable advice in conducting the study.

\section{Conflict of Interest}

The authors declare no conflict of interest.

\section{REFERENCES}

1. Spray J. Review of intravenous lipid emulsion therapy. J Infus Nurs 2016; 39(6):377-80.

2. Litonius ES. Treatment of acute intoxication with intravenous lipid emulsion - animal and human studies [dissertation]. [Internet] Helsinki: Unigrafi Oy; 2012. Available from: https://helda.helsinki.fi/bitstream/handle/10138/35261/treatmen.pdf?.1

3. Sirianni AJ, Osterhoudt KC, Calello DP, et al. Use of lipid emulsion in the resuscitation of a patient with prolonged cardiovascular collapse after overdose of bupropion and lamotrigine. Ann Emerg Med 2008; 51:412-5.

4. St-Onge M, Anseeuw K, Cantrell FL, et al. Experts consensus recom-

Table 1. Dosage of LE at the Clinic of Toxicology at the Naval Hospital-Varna

\begin{tabular}{lll}
\hline Severity of the acute intoxication & Dose of the LE & LE infusion rate \\
\hline Mild acute intoxication & $0.3 \mathrm{ml} / \mathrm{kg}$ in 24 hours & $20 \mathrm{ml} / \mathrm{h}(500 \mathrm{ml} / 24 \mathrm{~h})$ \\
\hline Moderate acute intoxication & $0.6 \mathrm{ml} / \mathrm{kg}$ for 24 hours & $40 \mathrm{ml} / \mathrm{h}(1000 \mathrm{ml} / 24 \mathrm{~h})$ \\
\hline \multirow{2}{*}{ Severe acute intoxication } & $1.5 \mathrm{ml} / \mathrm{kg}$ for $5 \mathrm{~min}$, followed by continuous infusion of & $100 \mathrm{ml} / 5 \mathrm{~min}+400 \mathrm{ml} / 55 \mathrm{~min}$ \\
& $0.3 \mathrm{ml} / \mathrm{kg}$ or $0.6 \mathrm{ml} / \mathrm{kg}$ for 24 hours. & $40 \mathrm{ml} / \mathrm{h}(1000 \mathrm{ml} / 24 \mathrm{~h})$ \\
\hline ASRA guidelines for the treatment of & $1.5 \mathrm{ml} / \mathrm{kg}$ for $1 \mathrm{~min}$, followed by continuous infusion of & $100 \mathrm{ml} / \mathrm{min}$ \\
local anesthetic systemic toxicity & $0.25 \mathrm{ml} / \mathrm{kg}$ for $30-60$ min. & $20 \mathrm{ml} / \mathrm{h}$ \\
\hline
\end{tabular}

The maximum dose of LE described in the literature is $7000 \mathrm{ml}$ in 24 hours 
mendations for the management of calcium channel blocker poisoning in adults. Crit Care Med 2017; 45(3):306-15.

5. Weinberg GL. Treatment of local anesthetic systemic toxicity (LAST). Reg Anesth Pain Med 2010; 35:188-93.

6. Harvey M, Cave G, Kazemi A. Intralipid infusion diminishes return of spontaneous circulation after hypoxic cardiac arrest in rabbits. Anesth Analg 2009; 108:1163-8.

7. Purg D, Markota A, Grenc D, et al. Low-dose intravenous lipid emulsion for the treatment of severe quetiapine and citalopram poisoning. Arh Hig Rada Toksikol 2016; 67(2):164-6.

8. Paskaleva I, Shmilev T. About some critical conditions in the course of acute poisoning in children. In: Proceedings of the National Conference on Clinical Toxicology, Sunny Beach, Burgas, Bulgaria 2017.

9. Medicinal products authorized in the Republic of Bulgaria. Bulgarian drug agency. Available from: https://www.bda.bg/images/stories/documents/register/Mp.htm

10. Rothschild L, Bern S, Oswald S, et al. Intravenous lipid emulsion in clinical toxicology. Scand J Trauma Resusc Emerg Med 2010; 18:51.

11. Foxall G, McCahon R, Lamb J, et al. Levobupivacaine-induced seizures and cardiovascular collapse treated with Intralipid. Anaesthesia 2007; 62:516-8.

12. Ludot H, Tharin JY, Belouadah M, et al. Successful resuscitation after ropivacaine and lidocaine-induced ventricular arrhythmia fol- lowing posterior lumbar plexus block in a child. Anesth Analg 2008; 106:1572-4

13. Litz RJ, Popp M, Stehr SN, et al. Successful resuscitation of a patient with ropivacaine-induced asystole after axillary plexus block using lipid infusion. Anaesthesia 2006; 61:800.

14. Litz RJ, Roessel T, Heller AR, et al. Reversal of central nervous system and cardiac toxicity after local anesthetic intoxication by lipid emulsion injection. Anesth Analg 2008; 106:1575-7.

15. McCutchen T, Gerancher JC. Early intralipid therapy may have prevented bupivacaine-associated cardiac arrest. Reg Anesth Pain Med 2008; 33:178-80.

16. Koyama Y, Moro K, Nakano M, et al. Intravenous carnitine administration in addition to parenteral nutrition with lipid emulsion may decrease the inflammatory reaction in postoperative surgical patients. J Clin Med Res 2017; 9(10):831-7.

17. Young AC, Velez LI, Kleinschmidt KC. Intravenous fat emulsion therapy for intentional sustained-release verapamil overdose. Resuscitation 2009; 80:591-3.

18. Vukovic-Ercegovic G, Perkovic-Vukcevic N, Bordevic S, et al. Successful usage of intravenous lipid emulsion in treatment of acute verapamil poisoning: A case report. Vojnosanitetski Pregled. Directory of Open Access Journals 2017; 74(3):278-81.

19. Chu J, Medlej K, Bania T, et al. The effect of intravenous fat emulsions in nifedipine toxicity. Acad Emerg Med 2009; 16:226. 


\title{
Дозировка липидных эмульсий в качестве антидота к липидорастворимым веществам
}

\author{
Габриэла Кехайова, Снежа Златева, Петко Маринов \\ Кафедра фармакологии, токсикологии и фармакотерапии, Фармацевтический факультет, Медицинский университет, Варна, Болгария
}

Адрес для корреспонденции: Габриэла Кехайова, Кафедра фармакологии, токсикологии и фармакотерапии, Фармацевтический факультет, Медицинский университет, Варна, Болгария; E-mail: gabi_stier@yahoo.com; Тел.: +359 883519926

Дата получения: 1 октября 2020 Дата приемки: 4 ноября 2021 Дата публикации: 31 декабря 2021

Образец цитирования: Kehayova G, Zlateva S, Marinov P. Dosage of lipid emulsions as an antidote to lipid-soluble substances. Folia Med (Plovdiv) 2021;63(6):913-8. doi: 10.3897/folmed.63.e59216

\section{Резюме}

Введение: Липидные эмульсии все чаще используются в качестве антидота при отравлении липофильными лекарственными средствами. Доза, определенная Американским обществом региональной анестезии, предназначена в первую очередь для лечения местной анестезирующей системной токсичности. Недостаточно информации о том, какая доза липидных эмульсий (ЛЭ) должна быть при других интоксикациях в зависимости от их степени тяжести.

Цель: Определить дозу ЛЭ при шоке или гемодинамической нестабильности у пациентов с острыми экзогенными интоксикациями, получавших ЛЭ.

Материалы и методы: Сорок девять пациентов с острыми липофильными лекарственными интоксикациями, которые проходили клинику токсикологии при Военно-морском госпитале Варна, лечились ЛЭ.

Статистический анализ проводился с использованием статистических функций в “Ехcel 2016” и программного пакета "Statistica 7.0".

Результаты: Процент пациентов с низкой дозой LE 0.3 мл/кг (93.87\%) был значительно выше, чем процент пациентов со средней (2.04\%) и высокой дозой (4.08\%). Высокую дозу ЛЭ 1.5 мл/кг, рекомендованную Американским обществом региональной анестезии, вводили двум пациентам (4.08\%). При тяжелых интоксикациях экзотоксическим шоком скорость введения варьирует от 20 мл/ч до 40 мл/ч.

Заключение: При тяжелых интоксикациях с кардиотоксическим синдромом и гемодинамической нестабильностью доза ЛЭ определяется Американским обществом региональной анестезии. При всех умеренных отравлениях можно вводить более низкие дозы ЛЭ 0.3-0.6 мл/кг в виде непрерывной внутривенной инфузии в течение 12-24-48 часов. При этих дозах побочных эффектов не наблюдалось.

\section{Ключевые слова}

дозировка липидной эмульсии, липидная эмульсия, острая лекарственная интоксикация 